\title{
Characterization and Intermediate Temperature Solid Oxide Fuel Cell Performances of $\mathrm{BaCe}_{0.9} \mathrm{Tm}_{0.1} \mathrm{O}_{3-\alpha}-\mathrm{KCl}-\mathrm{NaCl}$ Composite Electrolyte
}

\author{
Hui Miao ${ }^{1,3}$, Wei Chen ${ }^{2}$,Wenli Huㄴ, Hongtao Wang ${ }^{1,3, *}$ \\ ${ }^{1}$ School of Chemical and Material Engineering, Fuyang Normal University, Fuyang 236037, China \\ ${ }^{2}$ Fuyang Preschool Education College, Fuyang 236015, China \\ ${ }^{3}$ Anhui Provincial Key Laboratory for Degradation and Monitoring of Pollution of the Environment, \\ Fuyang 236037, China \\ *E-mail: hongtaoking3@163.com
}

doi: $10.20964 / 2019.05 .15$

Received: 31 January 2019 / Accepted: 5 March 2019 / Published: 10 April 2019

\begin{abstract}
In this study, $\mathrm{BaCe}_{0.9} \mathrm{Tm}_{0.1} \mathrm{O}_{3-\alpha}$ was prepared via a sol-gel combustion method using cerium nitrate, thulium oxide and barium nitrate as raw materials. Subsequently, it was reacted with the binary $\mathrm{KCl}$ $\mathrm{NaCl}$ salts to obtain $\mathrm{BaCe}_{0.9} \mathrm{Tm}_{0.1} \mathrm{O}_{3-\alpha}-\mathrm{KCl}-\mathrm{NaCl}$ composite electrolyte. The structure, morphology, conductivity and fuel cell performance of the obtained samples were investigated. SEM images showed that $\mathrm{KCl}-\mathrm{NaCl}$ inorganic molten salts covered and filled in the areas between the $\mathrm{BaCe}_{0.9} \mathrm{Tm}_{0.1} \mathrm{O}_{3-\alpha}$ particles. The highest power density and conductivity of $\mathrm{BaCe}_{0.9} \mathrm{Tm}_{0.1} \mathrm{O}_{3-\alpha}-\mathrm{KCl}-$ $\mathrm{NaCl}$ were $244.4 \mathrm{~mW} \cdot \mathrm{cm}^{-2}$ and $2.1 \times 10^{-1} \mathrm{~S} \cdot \mathrm{cm}^{-1} \mathrm{~S} \cdot \mathrm{cm}^{-1}$ at $700{ }^{\circ} \mathrm{C}$, respectively.
\end{abstract}

Keywords: Composite electrolyte; $\mathrm{BaCeO}_{3}$; Molten salt; Fuel cell; Conductivity

\section{$\underline{\text { FULL TEXT }}$}

(C) 2019 The Authors. Published by ESG (www.electrochemsci.org). This article is an open access article distributed under the terms and conditions of the Creative Commons Attribution license (http://creativecommons.org/licenses/by/4.0/). 